\title{
Morphological and Genetic Analyses of the Invasive Forest Pathogen Phytophthora austrocedri Reveal that Two Clonal Lineages Colonized Britain and Argentina from a Common Ancestral Population
}

\author{
Béatrice Henricot, Ana Pérez-Sierra, April C. Armstrong, Paul M. Sharp, and Sarah Green ${ }^{\dagger}$
}

First, third, and fifth authors: Forest Research, Northern Research Station, Roslin, Midlothian EH25 9SY, United Kingdom; second author: Forest Research, Alice Holt Lodge, Farnham, Surrey GU10 4LH, United Kingdom; and fourth author: Institute of Evolutionary Biology, University of Edinburgh, Edinburgh, EH9 3FL, United Kingdom.

Accepted for publication 23 July 2017.

\begin{abstract}
Phytophthora austrocedri is causing widespread mortality of Austrocedrus chilensis in Argentina and Juniperus communis in Britain. The pathogen has also been isolated from $J$. horizontalis in Germany. Isolates from Britain, Argentina, and Germany are homothallic, with no clear differences in the dimensions of sporangia, oogonia, or oospores. Argentinian and German isolates grew faster than British isolates across a range of media and had a higher temperature tolerance, although most isolates, regardless of origin, grew best at $15^{\circ} \mathrm{C}$ and all isolates were killed at $25^{\circ} \mathrm{C}$. Argentinian

analyses of nuclear and mitochondrial loci showed that all British isolates are identical. Argentinian isolates and the German isolate are also identical but differ from the British isolates. Single-nucleotide polymorphisms are shared between the British and Argentinian isolates. We concluded that British isolates and Argentinian isolates conform to two distinct clonal lineages of P. austrocedri founded from the same as-yet-unidentified source population. These lineages should be recognized and treated as separate risks by international plant health legislation.
\end{abstract} and British isolates caused lesions when inoculated onto both A. chilensis and J. communis; however, the Argentinian isolate caused longer lesions on A. chilensis than on J. communis and vice versa for the British isolate. Genetic

Phytophthora austrocedri (synonym: P. austrocedrae Gresl. \& E. M. Hansen, sp. nov.) is a filamentous oomycete plant pathogen first described in 2007 from southern Argentina, where it is associated with widespread mortality of the native cypress Austrocedrus chilensis (Cupressaceae) (Greslebin and Hansen 2010; Greslebin et al. 2007). It is a homothallic species characterized by Greslebin et al. (2007) as having semipapillate sporangia, oogonia with amphigynous antheridia, coralloid hyphae, and very slow growth of 1 to $2 \mathrm{~mm} \mathrm{day}^{-1}$ on V8 agar at an optimal temperature of $17.5^{\circ} \mathrm{C}$. A recent molecular phylogeny based on four mitochondrial loci placed $P$. austrocedri in subclade $\mathrm{d}$ of Phytophthora clade 8, which includes other forest pathogens such as $P$. ramorum and $P$. lateralis (Martin et al. 2014). The other known species most closely related to $P$. austrocedri are $P$. syringae and P. obscura, both of which cause foliar and shoot blights as well as cankers on trees and ornamental shrubs (Grünwald et al. 2012).

P. austrocedri was not reported outside Argentina until 2011, when investigations into dieback and mortality of Juniperus communis at two sites in northern Britain yielded a slow-growing Phytophthora sp. identified as $P$. austrocedri, based on culture morphology and analysis of its partial internal transcribed spacer (ITS) 1-5.8S-ITS2 sequence (Green et al. 2012). Subsequent surveys of wild populations of J. communis at numerous geographically separate sites in northern Britain carried out between 2012 and 2014 revealed a surprisingly wide distribution of $P$. austrocedri, with the pathogen causing root and stem infections and contributing to a severe decline of this ecologically important native conifer species (Green et al. 2015).

${ }^{\dagger}$ Corresponding author: S. Green; E-mail: sarah.green@forestry.gsi.gov.uk

*The $\boldsymbol{e}$-Xtra logo stands for "electronic extra" and indicates that one supplementary file and two supplementary tables are published online.

(c) Crown copyright 2017. This article is licensed under the terms of the Open Government License v3.0
Additional keywords: genetic diversity, morphology, oomycete, recombination.
Around the same time as the first findings on J. communis, P. austrocedri was also isolated from a single declining Calliptropsis nootkatensis (Nootka cypress or Alaskan yellow cedar) (Green et al. 2016) and a single declining Chamaecyparis lawsoniana (Lawson cypress or Port Orford cedar) (S. Green and G. A. MacAskill, unpublished data), both in urban locations near Glasgow, Scotland. The only other country where $P$. austrocedri has been reported is Germany, where a single isolate was obtained from a young J. horizontalis 'Glauca' plant growing in a nursery (Werres et al. 2014).

In Argentina, the population of $P$. austrocedri is clonal and this, together with its aggressive behavior on A. chilensis, strongly suggests that it has been introduced there (Vélez et al. 2014). Similarly, 10 British isolates from geographically separate sites were $100 \%$ identical across a partial sequence of the ITS locus, suggesting that the pathogen also has limited genetic diversity in Britain (Green et al. 2015). However, the ITS sequences reported from British and Argentinian isolates differed (Green et al. 2015), and the first isolate to be obtained from J. communis was found to have a slower growth rate at $17^{\circ} \mathrm{C}$ $\left(<0.5 \mathrm{~mm} \mathrm{day}^{-1}\right)$ (Green et al. 2012) compared with that reported for the Argentinian isolates (Greslebin et al. 2007). These dissimilarities raise the possibility that the epidemic in Britain is being caused by a different lineage of $P$. austrocedri that is not associated with the epidemic in Argentina (Green et al. 2015). A more in-depth morphological and genetic analysis of British, Argentinian, and German isolates of $P$. austrocedri is required in order to clarify the taxonomic status and evolutionary history of British isolates in relation to those from Argentina. Correct classification of the isolates is also important for regulatory policy aimed at containing the outbreaks in each country and preventing further international spread. Thus, the objectives of this study were to characterize isolates of $P$. austrocedri from J. communis in Britain using a range of morphological criteria in direct comparison with isolates collected from A. chilensis in Argentina and J. horizontalis in Germany, and to clarify the epidemiological and evolutionary relationships among all isolates. 


\section{MATERIALS AND METHODS}

Cultures and morphology. Isolates originating from Britain (hereafter referred to as UK isolates) were collected from J. communis, as described by Green et al. (2015), and isolates from Argentina (ARG) (Vélez et al. 2014) were collected from A. chilensis by Greslebin et al. (2007) and Greslebin and Hansen (2010) (Table 1). One isolate (BBA) originated from $J$. horizontalis Glauca in Germany (GER) (Werres et al. 2014) (Table 1). Single hyphal-tip cultures were obtained from field isolates by transferring individual hyphal tips onto clarified V8 juice agar (V8A; $2 \mathrm{~g}$ of $\mathrm{CaCO}_{3}, 200 \mathrm{ml}$ of V8 juice, and $15 \mathrm{~g}$ of agar in $800 \mathrm{ml}$ of distilled water) or carrot agar (CA; $200 \mathrm{~g}$ of carrot, macerated and mixed in a blender with approximately $500 \mathrm{ml}$ of cold tap water and filtered through a muslin cloth) (Erwin and Ribeiro 1996). The final volume was adjusted to $1,000 \mathrm{ml}$ and $15 \mathrm{~g}$ of agar was added and autoclaved twice at $121^{\circ} \mathrm{C}$ for $30 \mathrm{~min}$. For long-term storage, the isolates were subcultured onto oatmeal agar slopes (Sigma Aldrich, St. Louis) and covered with paraffin oil. The slopes were maintained in the dark at $10^{\circ} \mathrm{C}$.

For the description of the colony morphology, isolates BT3, GA197, GA3, GAT6, GK2, SS2, TDJ3, and TDJ20 (UK); Phy-195, Phy-215, and Phy-318 (ARG); and BBA (GER) (Table 1) were grown at $17^{\circ} \mathrm{C}$ in the dark for 1 month on four different media: V8A, $\mathrm{CA}$, malt extract agar (MEA; $20 \mathrm{~g}$ of malt extract, $15 \mathrm{~g}$ of agar, and $1,000 \mathrm{ml}$ of distilled water), and potato dextrose agar (PDA; $39 \mathrm{~g}$ in 1,000 $\mathrm{ml}$ of distilled water) (Oxoid Ltd., Hampshire, United Kingdom). Morphological analyses of reproductive structures were conducted on all $P$. austrocedri isolates listed in Table 1. Two of the ARG isolates included in this study (Phy-195 and Phy-215) were also included in the original description of the species by Greslebin et al. (2007). Sporangia were produced by flooding, with nonsterile pond water, $10-\mathrm{mm}^{2}$ segments of mycelium on V8A agar cut from the growing margins of 21-day-old colonies and incubating them at $16^{\circ} \mathrm{C}$ in the dark for 4 to 5 days. For each isolate, dimensions and characteristic features of 50 mature sporangia, chosen arbitrarily, were determined at $\times 400$ and $\times 1,000$ (Leica, Milton Keynes, United Kingdom). Dimensions and characteristic features of 50 mature oogonia, oospores, and antheridia were also measured as above on $10-\mathrm{mm}^{2}$ segments of mycelium cut from the center of 6- to 8-weekold colonies on V8A $+\beta$-sitosterol cultures $(100 \mathrm{ml}$ of V8 filtered through cloth, $2 \mathrm{~g}$ of $\mathrm{CaCO}_{3}, 30 \mathrm{mg}$ of $\beta$-sitosterol, $900 \mathrm{ml}$ of distilled water, and $15 \mathrm{~g}$ of agar) grown at $16^{\circ} \mathrm{C}$ in the dark. For each isolate, the oospore wall index was calculated as the ratio between the volume of the oospore wall and the volume of the entire oospore (Dick 1990).

Growth rate on different media. The following isolates were included in this experiment: BT3, GA3, GK2, SS2, TDJ3, and TDJ20
(UK); Phy-211 and Phy-257 (ARG); and BBA (GER) (Table 1). Mycelial plugs ( $5 \mathrm{~mm}$ in diameter) were taken from the actively growing margins of 21- to 28-day-old colonies of each isolate and placed centrally onto 90-mm-diameter Petri plates containing either CA, PDA, V8A, V8A amended with extract from J. communis $(15 \mathrm{~g}$ of green juniper foliage blended with $200 \mathrm{ml}$ of sterile distilled water until completely macerated, filtered through cheesecloth, and made up to $1,000 \mathrm{ml}$ with V8A, as described above), or corn meal agar (CMA; Oxoid Ltd.). Six replicate plates per isolate-medium combination were incubated at $17^{\circ} \mathrm{C}$ in the dark in a randomized complete-block design that was blocked according to replicate number. After 28 days, the radius of each colony was measured from the outer edge of the inoculum plug to the furthest growth point of each colony. The experiment was performed twice. Average daily growth rates of the nine $P$. austrocedri isolates across the five media were analyzed by analysis of variance (ANOVA) to test the effects of isolate and growth medium. The two trials of the experiment were incorporated in the underlying structure of the ANOVA design and growth rate data were square-root transformed to account for greater variability in fastergrowing isolates.

Growth rate at different temperatures. All $P$. austrocedri isolates listed in Table 1 were included in this experiment. Mycelial plugs ( $5 \mathrm{~mm}$ in diameter) from 14-day-old colonies of each isolate were placed centrally on 90 -mm-diameter V8A plates and incubated at $17^{\circ} \mathrm{C}$ in the dark to achieve linear growth (Greslebin et al. 2007). After 7 days, the diameter of each colony was measured in two directions (at right angles) and the diameters drawn on the underside of each plate with a permanent marker pen. Four replicate plates of each isolate were then incubated at 5, 10, 15, 20, 25, and $30^{\circ} \mathrm{C}$ in the dark for a further 14 days, after which the diameters of each colony were remeasured as above and the mean daily radial growth rate (in millimeters) was calculated. Plates from temperatures where growth was arrested were subsequently incubated at $17^{\circ} \mathrm{C}$ to determine whether the isolates were still viable. The experiment (trial) was performed twice. Because colony growth was arrested at 25 but not at $20^{\circ} \mathrm{C}$, a second experiment was set up as above but with isolates incubated at $22.5^{\circ} \mathrm{C}$ only. This experiment was also repeated. Linear mixed-effects models were used to determine the effects of trial, temperature and country of origin on (i) maximum growth rate per isolate and (ii) linear rate of increase in growth with temperature (to maximum) per isolate, using daily radial growth rate. Posthoc tests were carried out using Wald's $\chi^{2}$ test applied to main effects and interactions and, where appropriate, using general linear hypothesis testing (GLHT) on main effects in the multcomp package in $\mathrm{R}$ (Hothorn et al. 2008).

Pathogenicity assays. Pathogenicity assays were conducted in which one UK isolate (TDJ3) and one ARG isolate (Phy-195)

TABLE 1. Phytophthora austrocedri isolates from Juniperus communis, J. horizontalis, and Austrocedrus chilensis used in this study

\begin{tabular}{|c|c|c|c|}
\hline Isolate code & Host & Location & Source $^{\mathrm{a}}$ \\
\hline TDJ3, TDJ6, TDJ20 & J. communis & Teesdale, County Durham, England & FR-NRS \\
\hline GA3, GAT6, GA197 & J. communis & Glen Artney, Stirling, Scotland & FR-NRS \\
\hline GK2 & J. communis & Glenkirk, Highland, Scotland & FR-NRS \\
\hline BT3 & J. communis & Blea Tarn, Cumbria, England & FR-NRS \\
\hline BF207 & J. communis & Blowick Fell, Cumbria, England & FR-NRS \\
\hline BBA & J. horizontalis & Plant nursery, Germany & JKI \\
\hline Phy-211, Phy-215 & A. chilensis & $\begin{array}{l}\text { Los Alcerces National Park, Chubut } \\
\text { Province, Argentina }\end{array}$ & CIEFAP \\
\hline Phy-276, Phy-318 & A. chilensis & Epuyén, Chubut Province, Argentina & CIEFAP \\
\hline Phy-292 & A. chilensis & $\begin{array}{l}\text { Victoria Island, Nahuel Huapi National Park, } \\
\text { Neuquén Province, Argentina }\end{array}$ & CIEFAP \\
\hline Phy-257, Phy-301 & A. chilensis & $\begin{array}{l}\text { Lanin National Park, Neuquén Province, } \\
\text { Argentina }\end{array}$ & CIEFAP \\
\hline
\end{tabular}

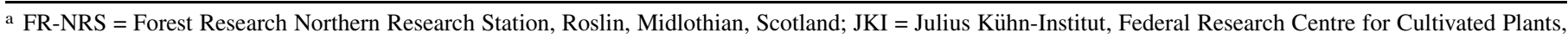
Institute for Plant Protection in Horticulture and Forests, Braunschweig, Germany; and CIEFAP = Centro de Investigación y Extensión Forestal, Andino Patagónico, Esquel, Chubut, Argentina. 
(Table 1) were each inoculated onto both J. communis and A. chilensis and lesion development assessed. For J. communis, intact, 4-year-old potted plants of Scottish provenance were used. Due to the difficulties in obtaining potted plants of A. chilensis, excised shoots (approximately $30 \mathrm{~cm}$ long) of this species were collected from a single specimen tree growing at Benmore Botanic Gardens, Scotland. For inoculation of J. communis, a 3-mmdiameter plug of bark was removed $2 \mathrm{~cm}$ above soil level using a sterile cork borer and a 3-mm-diameter plug of mycelium cut from a 21-day-old colony of each isolate on V8A was placed, mycelial side down, onto the cambium. The inoculation point was wrapped in damp sterile cotton wool secured in place with Parafilm and covered with aluminum foil (Greslebin and Hansen 2010). Excised shoots of A. chilensis were inoculated at their midpoint as described above for J. communis. In all, 10 plants or shoots of each host species were inoculated with each isolate and 10 plants or shoots per species were inoculated with sterile V8A as controls. Inoculated J. communis plants were maintained in a glasshouse for 7 weeks at $16 \pm 2{ }^{\circ} \mathrm{C}$, with a $12 \mathrm{~h}$-photoperiod. The plant material was arranged in a randomized complete block design during incubation. Inoculated shoots of A. chilensis were placed in sealed plastic bags containing a damp cotton wool ball with six shoots per bag; two inoculated with each isolate and two controls. The bags were then incubated at $16^{\circ} \mathrm{C}$ in the dark for 3 weeks. After the incubation period, the lengths of lesions in the phloem were measured and reisolations were attempted from the margins of all lesions onto synthetic mucor agar of Elliott et al. (1966), with the addition of antibiotics as described by Brasier et al. (2005). The assay (trial) was performed twice. Linear mixed-effects models were used to determine the effects of trial and isolate on lesion length for both host species. Because trial was not found to have a significant effect on lesion length in initial analyses, it was subsequently treated as a random factor in the mixed-effects model, with individual block nested within. The control treatment showed significantly less variance than the two isolate treatments; therefore, the mixed-effects models included weighting factors, allowing the variance to vary by isolate type. Posthoc tests were carried out using the multcomp package in R (Hothorn et al. 2008).

Phylogenetic analysis. Cultures of UK, ARG, and GER P. austrocedri isolates were transferred onto $\mathrm{CA}$ plates overlaid with a washed and autoclaved cellophane disc, and incubated at $16^{\circ} \mathrm{C}$ in the dark. After 14 to 21 days, the mycelium was scraped from the cellophane and stored at $-80^{\circ} \mathrm{C}$ until DNA extraction, when the mycelia were ground in liquid nitrogen using a pestle and mortar and the DNA extracted using the Plant DNeasy Plant Mini Kit (Qiagen, Hilden, Germany), according to the manufacturer's instructions.

The complete ribosomal RNA ITS region and the $5.8 \mathrm{~S}$ gene were amplified for the following isolates: all UK; Phy-195, Phy-215, Phy-276, Phy-292, Phy-301, and Phy-318 (ARG); and BBA (GER) (Table 1) by a seminested polymerase chain reaction (PCR) using primers ITS4 (White et al. 1990) and DC6 (Bonants et al. 1997) in the first round and ITS4 and ITS6 (Cooke et al. 2000) in the second round. The PCR conditions for both rounds were the same as those described by Cooke et al. (2000), except with annealing temperatures of $62^{\circ} \mathrm{C}$ in the first round and $63^{\circ} \mathrm{C}$ in the second round. Six additional gene regions were amplified for the following isolates: BT3, GA3, GAT6, GK2, SS2, TDJ3, TDJ6, and TDJ20 (UK); Phy-195 and Phy-215 (ARG); and BBA (GER) (Table 1). These were the mitochondrial genes cox 1 (primers FM83 and FM84) (Martin and Tooley 2003) and cox2 (primers FM35 and Phy10b) (Martin et al. 2014), the nuclear genes encoding $\beta$-tubulin (primers Btub_F1A and Btub_R1A) (Blair et al. 2008), elongation factor $1 \alpha(E F-1 \alpha)$ (primers ELONGF1 and ELONGR1) (Kroon et al. 2004), heat shock protein 90 (HSP90) (primers HSP90_F1 and HSP90_F2) (Blair et al. 2008), and the 60S ribosomal protein L10 (RPL10) (primers 60SL10_for and 60SL10_rev) (Blair et al. 2008). All PCR were carried out in $25 \mu \mathrm{l}$ of total volume containing $1 \mu \mathrm{l}$ of DNA and 10 pmol each primer using PCR beads (Amersham Pharmacia Biotech, Little Chalfont, UK), according to the manufacturer's instructions. Reactions were performed in a Progene thermocycler

TABLE 2. Morphological characters and dimensions (in micrometers) of Phytophthora austrocedri isolates originating from the United Kingdom, Germany, and Argentina

\begin{tabular}{|c|c|c|c|c|}
\hline & United Kingdom & Germany & Argentina & Argentina $^{\mathrm{a}}$ \\
\hline $\begin{array}{l}\text { Number of isolates } \\
\text { investigated }\end{array}$ & 10 & 1 & 8 & 11 \\
\hline Sporangia & $\begin{array}{l}\text { Variable mainly ellipsoid, } \\
\text { ovoid, broad ovoid and } \\
\text { distorted shape (mouse- } \\
\text { shaped, kidney, asymmetrical) }\end{array}$ & $\begin{array}{l}\text { Variable mainly ellipsoid, } \\
\text { ovoid, and distorted shape } \\
\text { (mouse-shaped, kidney, } \\
\text { asymmetrical) }\end{array}$ & $\begin{array}{l}\text { Variable mainly ellipsoid, } \\
\text { ovoid, broad ovoid and } \\
\text { distorted shape (mouse- } \\
\text { shaped, kidney, asymmetrical) }\end{array}$ & $\begin{array}{l}\text { Ovoid, obpyriform, limoniform } \\
\text { or ellipsoid, infrequently } \\
\text { distorted }\end{array}$ \\
\hline $1 \times b$ mean & $48.1 \pm 0.6 \times 31.3 \pm 0.2$ & $47.9 \pm 1.0 \times 35.5 \pm 0.02$ & $51.8 \pm 0.6 \times 36.4 \pm 0.3$ & $50 \pm 12 \times 36 \pm 7$ \\
\hline $\begin{array}{l}\text { Range of isolate } \\
\text { means }\end{array}$ & $40.1-58 \times 28.9-35.2$ & $\ldots$ & $44.3-64.5 \times 32.5-43.7$ & $37.7-59.9 \times 29.6-42.6$ \\
\hline Total range & $9.9-98.2 \times 15.5-43.8$ & $32.5-62.0 \times 26.69-48.23$ & $24.2-89.3 \times 20.9-55.7$ & $22-83 \times 17-58$ \\
\hline $1 / \mathrm{b}$ ratio & $1.5 \pm 0.02$ & $1.4 \pm 0.02$ & $1.4 \pm 0.01$ & $1.4 \pm 0.2$ \\
\hline Papilla thickness & $3.6 \pm 0.1$ & $2.8 \pm 0.2$ & $3.2 \pm 0.1$ & $1-3(-5)$ \\
\hline Oogonia & Mostly golden, smooth walls & $\ldots$ & $\begin{array}{l}\text { Mostly golden to light golden, } \\
\text { smooth walls }\end{array}$ & $\begin{array}{l}\text { Hyaline to light brown, smooth } \\
\text { walls }\end{array}$ \\
\hline Mean diameter & $35.7 \pm 0.26$ & $\ldots$ & $38 \pm 0.29$ & $38.5 \pm 7 \times 39 \pm 6$ \\
\hline $\begin{array}{l}\text { Range of isolate } \\
\text { means }\end{array}$ & $28.6-38.7$ & $\cdots$ & $36.6-40.4$ & $32.8-42.5$ \\
\hline Total range & $18.65-49.61$ & $\ldots$ & $19.7-52.9$ & $22-56$ \\
\hline Oospores & Globose & $\ldots$ & Globose & Globose \\
\hline Plerotic oospores & $27 \%$ (8 to $60 \%)$ & $\ldots$ & $13 \%$ (6 to $30 \%)$ & No data \\
\hline Mean diameter & $31.1 \pm 0.24$ & $\ldots$ & $32.9 \pm 0.27$ & $31 \pm 6$ \\
\hline Total range & $15.9-46.8$ & $\ldots$ & $17.5-50.9$ & $17-49$ \\
\hline Wall diameter & $2.2 \pm 0.03$ & $\ldots$ & $1.5 \pm 0.05$ & $1-2(-3)$ \\
\hline Oospore wall index & $0.57 \pm 0.004$ & $\ldots$ & $0.5 \pm 0.01$ & No data \\
\hline Abortion rate $(\%)$ & $10.2(4.3-31)$ & 100 & $78(59-100)$ & No data \\
\hline Antheridia & $\begin{array}{l}\text { Amphigenous, predominantly } \\
\text { hyaline but some also golden, } \\
\text { one celled }\end{array}$ & $\cdots$ & $\begin{array}{l}\text { Amphigenous, predominantly } \\
\text { hyaline but some also golden, } \\
\text { one celled }\end{array}$ & $\begin{array}{l}\text { Amphigenous, hyaline, one } \\
\text { celled }\end{array}$ \\
\hline $1 \times \mathrm{w}$ mean & $13.9 \pm 0.15 \times 13.5 \pm 0.13$ & $\ldots$ & $15.2 \pm 0.19 \times 13.9 \pm 0.17$ & $15.5-20.5 \times 13.5-15$ \\
\hline Total range & $8-24.3 \times 5.1-20.8$ & $\ldots$ & $9.1-24.1 \times 7.2-26.4$ & $10-30 \times 8-20$ \\
\hline
\end{tabular}

a Data from Greslebin et al. (2007). 
(Techne, Cambridge, UK). Products were visualized under UV light with $5 \%$ ( $\mathrm{vol} / \mathrm{vol}$ ) ethidium bromide $(10 \mathrm{mg} / \mathrm{ml})$ in $1 \%$ agarose gels in Tris-borate-EDTA. PCR products were purified using QIAquick Gel Extraction Kits (Qiagen) following the manufacturer's instructions and sequenced by a commercial sequencing service (Macrogen, Seoul, South Korea or Edinburgh Genomics, Edinburgh, UK). Templates were sequenced in both directions with the primers used in amplification. Additional sequencing primers were used for $\operatorname{cox} 1$ (FM85 and FM50) (Martin and Tooley 2003), cox2 (FM82 and FM80) (Martin et al. 2014), $\beta$-tubulin (Btub_F2 and Btub_R2) (Blair et al. 2008), and HSP90 (HSP90_F1int, HSP90_F2 and HSP90_R1) (Blair et al. 2008).

A consensus sequence was computed from the forward and reverse sequences with SEQMAN from the LASERGENE package (v 8.0.2; DNAstar, Madison, WI). The sequences were edited and aligned using BIOEDIT, v 7.0.5 (Hall 1999). All polymorphisms were rechecked by examining the peaks on the chromatograms to ensure that the base calls were correct. Sequences with heterozygous sites (ITS, $\beta$-tubulin, RPL10, and $E F-1 \alpha$ ) were phased to determine haplotypes by aligning trimmed Illumina and PacBio whole-genome sequence reads for UK isolate TDJ3 and ARG isolate Phy-195 to a reference sequence for each gene of interest and removing PCR duplicates. Variants were called in each gene using HaplotypeCaller, and phased with ReadBackedPhasing (GATK tools; Broad Institute, Cambridge, MA). Newly determined sequences have been deposited at the GenBank/EMBL database (accession numbers KU953962 to KU954060).

Because the sequences of all UK isolates were identical, and all sequences from ARG and GER isolates were identical, representative haplotype sequences per genotype were used for each locus in the phylogenetic analyses. The P. austrocedri sequences were compared with representative sequences from the clade $8 \mathrm{~d}$ species $P$. syringae and P. obscura (Supplementary Table S1). Sequences were aligned using CLUSTALW (Thompson et al. 1994), and all sites with a gap in any sequence were excluded from the phylogenetic analyses. Maximum-likelihood trees were estimated from nucleotide sequences using PhyML 3.0 (Guindon et al. 2010), with the general time-reversible model of sequence change and $\gamma$-distributed rate variation across sites (four categories); 1,000 bootstrap replicates were examined. Midpoint-rooted phylogenies were displayed using FigTree (https://github.com/rambaut/figtree/releases/tag/v1.4.3) and deposited in TreeBASE (https://treebase.org/).

\section{RESULTS}

Cultures and morphology. Due to exceptionally slow growth on PDA and MEA media, the colony morphology could only be described on V8A and CA. On these media, ARG and GER isolates had a white, woolly colony, with aerial mycelium covering almost the full plate, and were easily grouped into one morphotype, being either uniform or faintly stellate. UK isolates presented different colony morphologies and could not be grouped into morphotypes, having smaller colonies than ARG and GER isolates, with white aerial mycelium that ranged from cottony to woolly to felty, dense or sparse mycelium, and either diffused or entire margins. The colony morphology of isolates on V8A is shown in Figure 1.

Sporangia of $P$. austrocedri isolates from UK and GER were produced abundantly in pond water but sporangia production was more variable for the ARG isolates. Only the UK isolates produced sporangia on solid media (V8A+ $\beta$-sitosterol). For all isolates, sporangia were mainly borne terminally on unbranched sporangiophores (Figs. 2A and 3A) and less frequently on branched sporangiophores (Fig. 2B and F). Less than $1 \%$ of sporangia were intercalary. Hyphal swellings were commonly produced and were sometimes formed close to the sporangial base (Fig. 2C). Sporangia were noncaducous and mostly semipapillate (Figs. 2A and 3A), infrequently papillate (Figs. $2 \mathrm{~B}$ and $\mathrm{E}$ and $3 \mathrm{~B}$ ) or nonpapillate (less than $15 \%$ over all isolates regardless of their origin) (Fig. 2D), and rarely bipapillate (Fig. 3F). Basal plug protrusions into sporangia were frequently observed (Fig. 2E). Sporangial shapes showed a wide variation, with no clear differences between UK, GER, and ARG isolates. Across all isolates, at least 15 different shapes were observed, the more common being ellipsoid (UK, 27.3\%; ARG, 42\%; and GER, 42\%) (Figs. 2A and D and 3C and F), ovoid (UK, 24.4\%; GER, 24\%; and ARG, 35\%) (Figs. 2B, C, and E and 3A), globose (UK, 6.2\%; GER, 2\%; and ARG, 3.2\%) (Figs. 2D and 3B), mouse-shaped or kidney shaped (UK, 9.2\%; GER, 20\%; and ARG, 13\%) (Fig. 3D), and broad ovoid (UK, 5.8\%; GER, 0\%; and ARG $1.8 \%$ ). A small proportion of the sporangia (UK, $6 \%$; GER, $0 \%$; and ARG, $4.5 \%$ ) were also distorted (such as S-shaped or club-shaped) (Fig. 2F and G). For all isolates, sporangia with lateral attachments were common (UK, 46\%; GER, 40\%; and ARG, 46\%) (Figs. 2C and 3B) and hyphal projections occurred infrequently (Figs. 2D and $3 C$ ). Sporangia with displaced apices were also observed (UK, $13 \%$; GER, 6\%; and ARG, 4\%) (Figs. 2G and 3E). The sporangial dimensions of the UK isolates overlapped with the sporangial dimensions for those of GER and ARG isolates (Table 2). The mean exit pore width (Fig. 2F) was 8.9, 9.8, and $8.7 \mu \mathrm{m}$ (UK, GER, and ARG, respectively). No chlamydospores were observed in any isolate.

All $P$. austrocedri isolates except one were homothallic, with gametangia produced on $\mathrm{V} 8 \mathrm{~A}+\beta$-sitosterol by most isolates within 6 weeks. One UK isolate (BT3) did not produce any gametangia. The percentage of oogonia or oospore abortion was lower in the UK isolates (mean over all isolates $=10.2 \%$ ) than in the ARG isolates (mean over all isolates $=78 \%$ ) (Fig. $3 \mathrm{G}$ and $\mathrm{H})$. The oogonia of the GER isolate were all aborted (Fig. $3 \mathrm{H}$ ) and this was observed again when the trial was repeated. Oogonia of UK and ARG isolates were borne terminally, golden in color, had smooth walls, and were usually globose to subglobose (Figs. $2 \mathrm{H}$ to $\mathrm{K}$ and 3I) or, rarely, ellipsoid (Fig. 3J). Oogonia dimensions of UK isolates were again similar to ARG isolates (Table 3). The majority of oospores were slightly aplerotic (Fig. 2H and I) but sometimes highly aplerotic (Figs. 2J and $\mathrm{K}$ and $3 \mathrm{I}$ and $\mathrm{J}$ ). The mean percentage of plerotic oospores across UK isolates was slightly higher than for ARG isolates, although the ranges overlapped (Table 3 ). The oospore diameters of UK and ARG isolates were similar (Table 3). The oospore walls of UK isolates (Fig. $2 \mathrm{H}$ to $\mathrm{K}$ ) were thicker than those of ARG isolates (Fig. 3I and J) but their oospore wall indices were similar (Table 3). The antheridia of UK and ARG isolates were

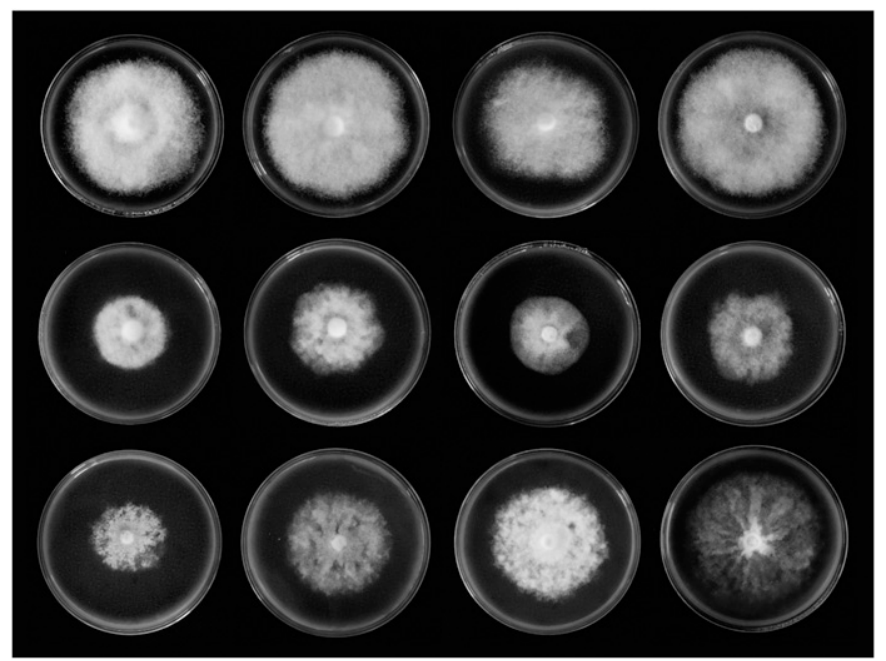

Fig. 1. Colony morphology of Phytophthora austrocedri on V8 juice agar after 28 days of growth at $17^{\circ} \mathrm{C}$ in the dark. Top row (left to right): ARG isolates Phy-215, Phy-195, and Phy-318 and GER isolate BBA. Middle row (left to right): UK isolates BT3, GA197, GA3, and GAT6. Bottom row (left to right): UK isolates TDJ3, SS2, TDJ20, and GK2. 
almost exclusively amphigynous (Figs. 2H and I and 3I and J). They were hyaline (Figs. 2H and 3I and J), sometimes golden (Fig. 2I), and of similar sizes across isolate groups (Table 3 ).

Growth rate on different media. Significant effects of isolate and medium (both $P<0.001$ ) were identified by the ANOVA. ARG
(Phy-211 and Phy-257) and GER (BBA) isolates grew significantly faster than UK isolates and growth rates on PDA were the slowest (Fig. 4). A significant interaction between the isolates and media was also identified $(P<0.001)$, the main interpretation of this being the additional variability in growth rates of UK isolates on CMA (Fig. 4).

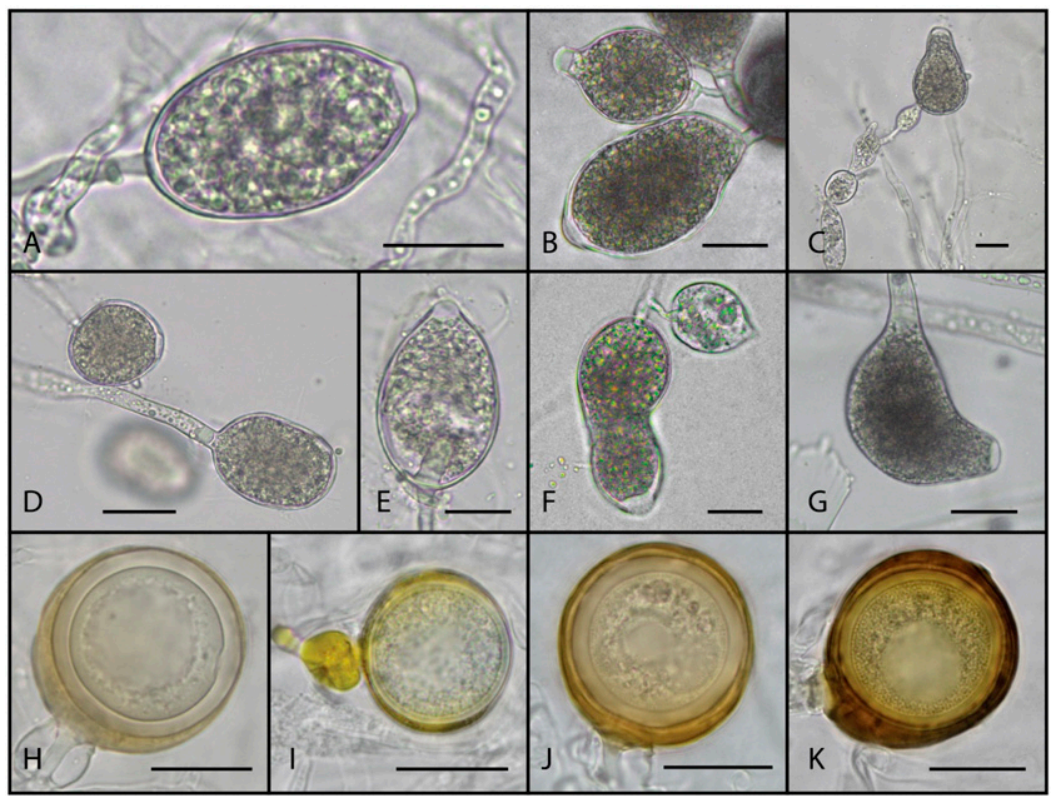

Fig. 2. Reproductive structures of UK isolates of Phytophthora austrocedri. A to G, Morphological variation of sporangia formed in pond water. A, Ellipsoid, semipapillate borne terminally on unbranched sporangiophore. B, Ovoid, papillate (upper) and ellipsoid, semipapillate (lower), both borne on branched sporangiophore. C, Ovoid, with lateral attachment and hyphal swellings close to sporangial base. D, Globose, semipapillate with hyphal projection (upper) and ellipsoid, nonpapillate (lower). E, Ovoid, papillate with basal plug protrusion. F, Distorted, on branching sporangiophore showing width of exit pore. G, Club shaped with displaced apex. $\mathbf{H}$ to K, Mature, globose to subglobose oogonia showing thick-walled oospores. H, Slightly aplerotic with hyaline, amphigynous antheridia. I, Slightly aplerotic with golden, amphigynous antheridia. $\mathbf{J}$ and $\mathbf{K}$, Clearly aplerotic. Scale bar $=20 \mu \mathrm{m}$.

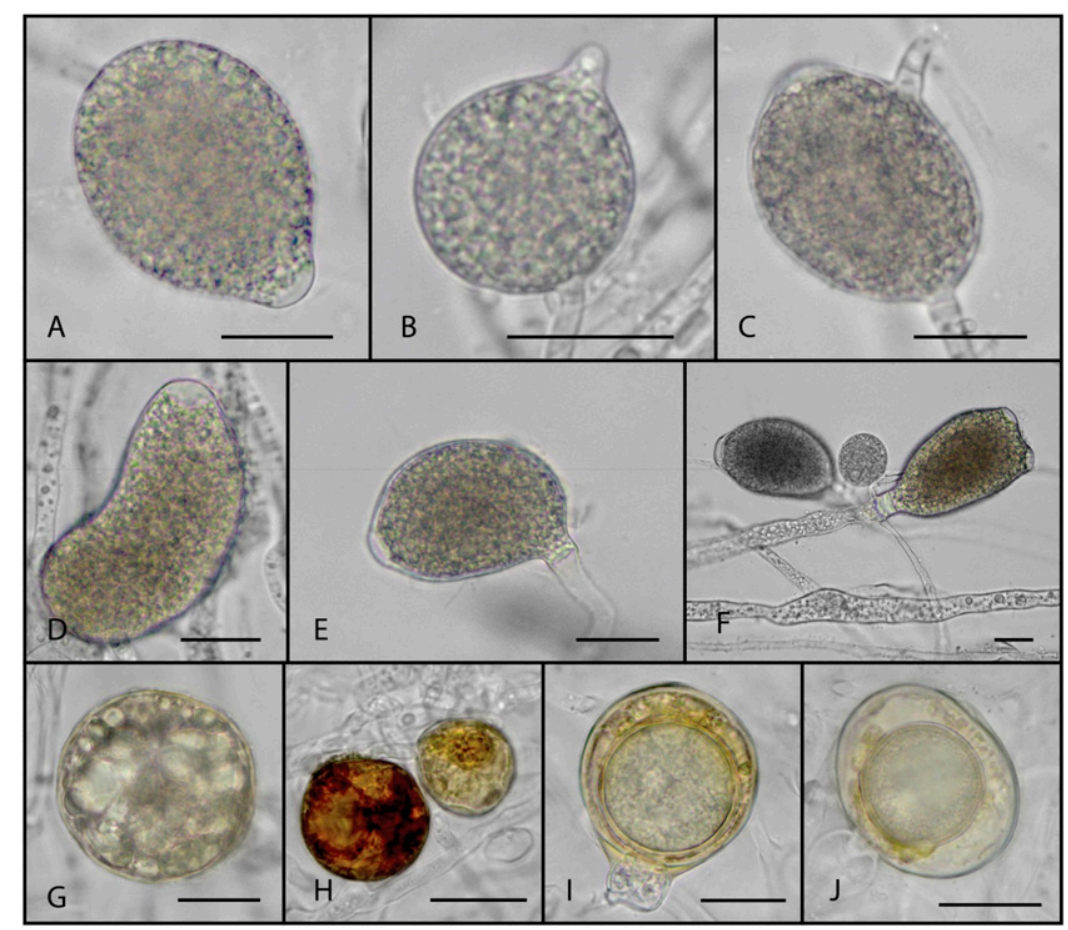

Fig. 3. Reproductive structures of ARG and GER isolates of Phytophthora austrocedri. A to F, Morphological variation of sporangia formed in pond water. A, Ovoid, semipapillate, borne on terminal sporangiophore. B, Globose, papillate, borne on lateral sporangiophore. C, Ellipsoid, semipapillate with hyphal projection. D, Kidney shaped, semipapillate. E, Semipapillate with displaced apex. F, Ellipsoid, semipapillate (left) and bipapillate (right). G and $\mathbf{H}$, Aborted oogonia. I and J, Mature oogonia with clearly aplerotic, thin-walled oospores. I, Globose with hyaline, amphigynous antheridia. J, Ellipsoid with hyaline, amphigynous antheridia. Scale bar $=20 \mu \mathrm{m}$. 
Growth rate at different temperatures. The linear mixedeffects model applied to maximum growth rates per isolate indicated significant effects of country of origin on maximum growth rate $(P<0.0001)$ but no significant effect of trial $(P>0.05)$. The effect of country of isolate origin was driven by significant differences between UK and ARG, and UK and GER $(P<0.001$, posthoc GLHT); there was no difference between isolates from ARG and GER. Isolates from ARG and GER had higher average maximum growth rates (1.29 and $1.64 \mathrm{~mm} /$ day, respectively) than UK isolates $(0.93 \mathrm{~mm} /$ day $)$. The linear mixed-effects model applied to the rate of increase in growth with temperature indicated significant effects of trial $(P=0.009)$, temperature $(P<0.001)$, and country of isolate origin $(P=0.005)$ and a significant interaction between temperature and country of origin $(P=0.002)$ on isolate radial growth rate. Analysis of the rate of increase in growth with temperature showed that UK isolates had the lowest absolute growth rate and least response to increase in temperature compared with ARG and GER isolates in both trials. The daily growth rate for all isolates across all temperatures in the two experimental trials is shown in Figure 5. The optimum temperature for growth for all UK and GER isolates and six of the eight ARG isolates was $15^{\circ} \mathrm{C}$; however, two ARG isolates (Phy-215 and Phy-257) grew fastest at $20^{\circ} \mathrm{C}$ (Figure 5). No isolates grew at 25 or $30^{\circ} \mathrm{C}$ and $\mathrm{UK}$ isolates failed to grow at $22.5^{\circ} \mathrm{C}$, whereas

TABLE 3. Mitochondrial DNA divergence within selected clade 8 Phytophthora spp. ${ }^{\text {a }}$

\begin{tabular}{lccccccc}
\hline & \multicolumn{3}{c}{$\operatorname{cox} 2$} & & \multicolumn{3}{c}{$\operatorname{cox} 1$} \\
\cline { 2 - 4 } \cline { 6 - 8 } Species & $\mathrm{N}$ & $\mathrm{L}$ & $\%$ & & $\mathrm{~N}$ & $\mathrm{~L}$ & $\%$ \\
\hline Phytophthora austrocedri & 13 & 885 & 1.47 & & 16 & 759 & 2.11 \\
P. ramorum & 4 & 899 & 0.44 & & 5 & 759 & 0.66 \\
$P$. lateralis & 8 & 529 & 1.51 & & 7 & 731 & 0.96 \\
$P$. obscura & 3 & 898 & 0.33 & & 2 & 759 & 0.26 \\
$P$. syringae & 6 & 911 & 0.66 & & 4 & 680 & 0.59 \\
\hline
\end{tabular}

a $\mathrm{N}=$ number of nucleotide differences, $\mathrm{L}=$ length of sequence, and $\%=$ percentage divergence. Values are presented for the most divergent pair of sequences within each species, taking representative lineage sequences for $P$. austrocedri, $P$. ramorum, and $P$. lateralis and all available sequences for P. obscura and P. syringae in GenBank (release 218).

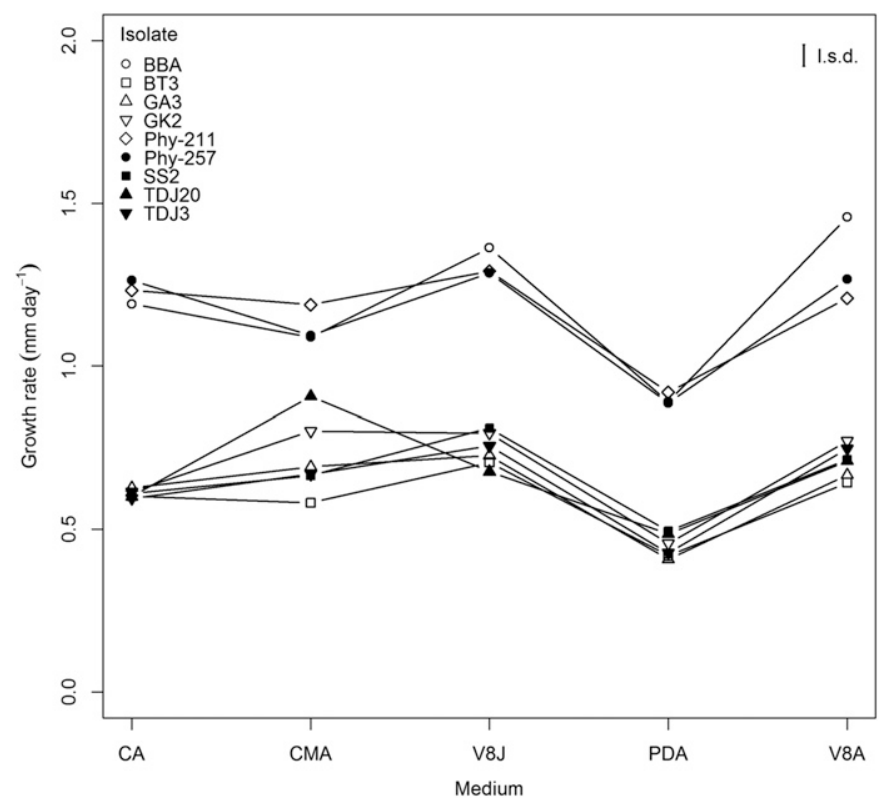

Fig. 4. Growth rate (millimeters per day) of isolates of Phytophthora austrocedri at $17^{\circ} \mathrm{C}$ on $\mathrm{V} 8$ juice agar (V8A), carrot agar (CA), corn meal agar (CMA), V8A amended with extract from J. communis (V8J), and potato dextrose agar (PDA).
ARG and GER isolates showed some limited growth at this temperature (Fig. 5). All of the isolates, regardless of their origin, were killed at $25^{\circ} \mathrm{C}$ and did not grow when they were subsequently transferred to $15^{\circ} \mathrm{C}$.

Pathogenicity assays. The linear mixed-effects model showed a significant effect of isolate on lesion length on both J. communis
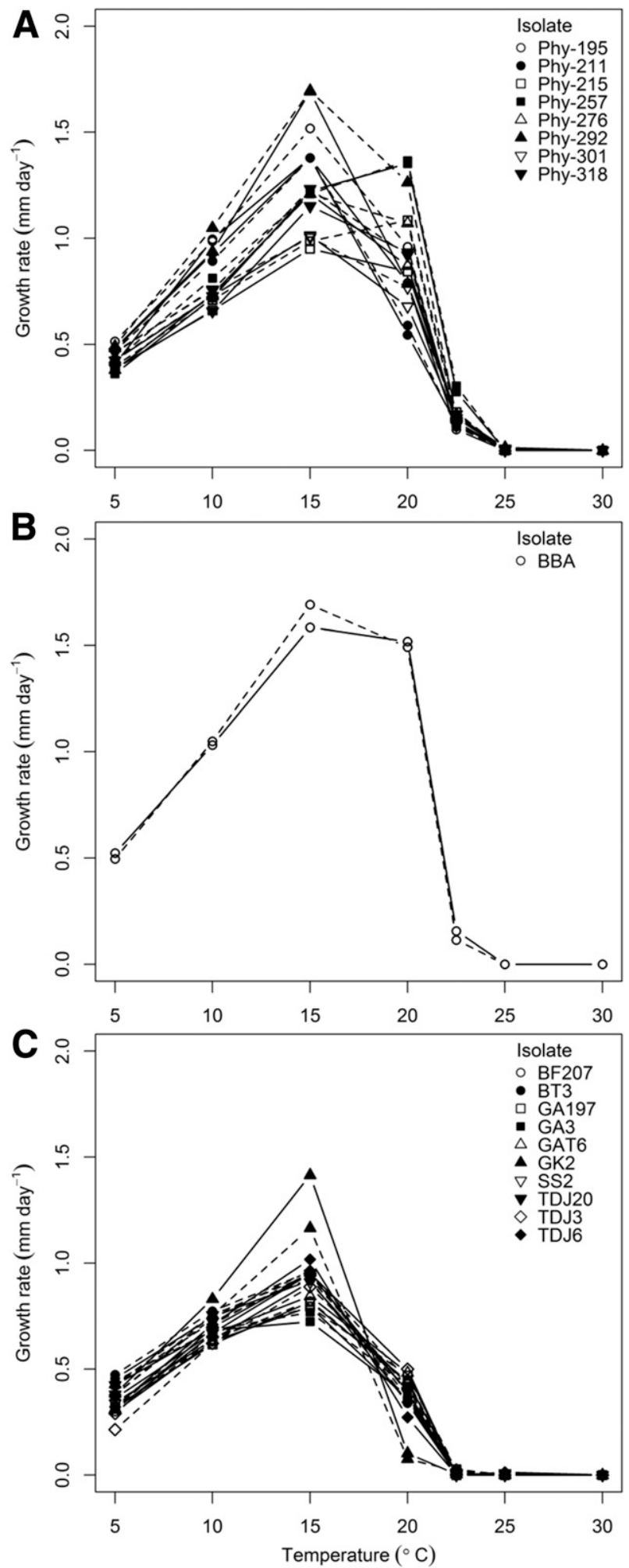

Fig. 5. Growth rate (millimeters per day) of isolates of Phytophthora austrocedri on V8 agar at different temperatures in two trials, whereby continuous lines and dashed lines represent growth rates in trials 1 and 2, respectively. A, ARG isolates; B, GER isolate; and $\mathbf{C}$, UK isolates. 
and $A$. chilensis $(P<0.0001)$. Both isolates (TDJ3 [UK] and Phy195 [ARG]) were pathogenic to J. communis and were reisolated from lesions. However, mean lesion length caused by isolate TDJ3 (UK) on $J$. communis was significantly $(P<0.05)$ greater than for Phy-195 (ARG) (Fig. 6). Only isolate TDJ3 caused lesions that were sufficient to girdle the plants (15\% of J. communis plants inoculated with TDJ3 were dead over both trials). On A. chilensis, isolate Phy195 caused significantly longer lesions than TDJ3 (Fig. 6) and was recovered from $85 \%$ of the stems over both trials. On both host species, isolates caused longer lesions than the control inoculations (Fig. 6) and P. austrocedri was not recovered from the controls.

Phylogenetic analyses. Across the combined mitochondrial DNA (partial cox 2 and $\operatorname{cox} 1$ gene) sequences $(2,100 \mathrm{bp}$ ) all eight UK isolates of $P$. austrocedri yielded identical sequences. The two ARG isolates (Phy-195 and Phy-215) had identical sequences but the UK and ARG isolates differed at $1.8 \%$ of sites, as well as by a deletion of 7 nucleotides within the region between $\operatorname{cox} 2$ and $\operatorname{cox} 1$ in the UK isolates (Supplementary Table S2); the BBA isolate (GER) was identical to the ARG isolates. Although these P. austrocedri haplotypes are more divergent than those found thus far for other clade $8 \mathrm{~d}$ species, they are much more closely related to one another than to the closest relative, P. obscura (Fig. 7A). Similarly, in the nuclear gene HSP90, all eight UK isolates had identical sequences, and ARG (Phy-195, Phy-215) and GER (BBA) isolates were identical, but the UK and ARG/GER sequences differed at 18 sites (1.1\% divergence). Again, although this level of divergence was higher than that seen among sampled isolates of $P$. obscura or $P$. syringae, nevertheless, the two $P$. austrocedri isolate groups were closely related (Fig. 7B). At three other nuclear loci ( $\beta$-tubulin, RPL10, and $E F-1 \alpha$ ), all of the $P$. austrocedri isolates contained a number of heterozygous sites, where two nucleotides were called. The same heterozygous sites were found in all UK isolates (with one exception; see below) and among Phy-195, Phy-215, and BBA, and some but not all heterozygous sites were shared by the two genotypes. The phase of the alternative nucleotides was determined from whole-genome sequence reads for representative isolates from the UK (TDJ3) and ARG (Phy-195) populations, yielding haplotype sequences for further analyses. In the resulting phylogenies for these loci (Fig. 7C to E), there was no evidence of separation between the haplotypes from the UK and ARG isolates, suggesting that the two lineages were founded from the same ancestral population. Indeed, the three heterozygous sites shared between the two lineages are most likely evidence of recombination during the divergence of these haplotypes, before the founder events. The identity of sequences within each lineage, including consistently shared heterozygous sites, indicates that the two lineages have each evolved clonally since they were founded. For one gene in one UK isolate ( $\beta$-tubulin, in TDJ20),

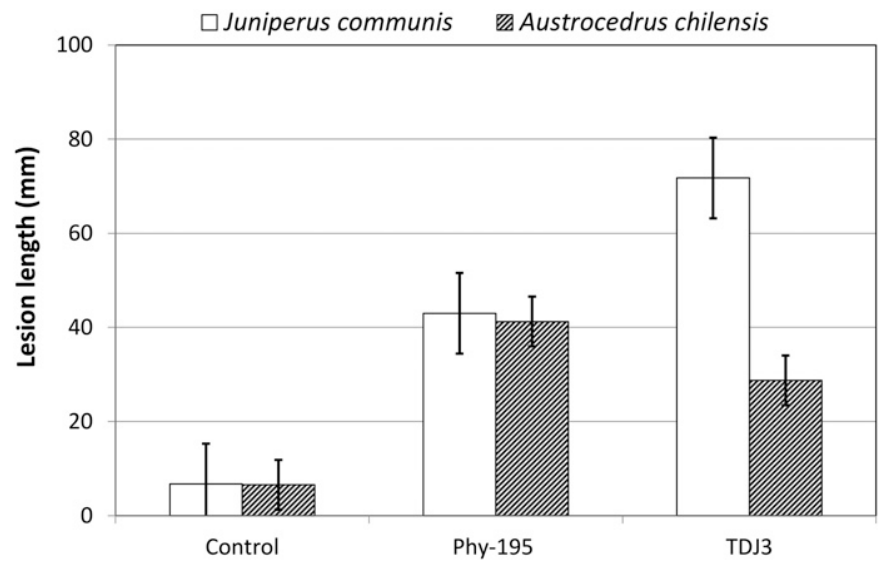

Fig. 6. Length (millimeters) of lesions in the bark of Juniperus communis and Austrocedrus chilensis 7 and 3 weeks, respectively, after inoculation with ARG isolate Phy-195, UK isolate TDJ3 of Phytophthora austrocedri, and sterile V8 agar as the control treatment predicted by the mixed-effects model for each inoculum type. Error bars = standard errors determined by the mixed-effect model. there was evidence of the loss of one of the haplotypes present in the founder of the lineage.

Sequences were also obtained for the ITS region of the ribosomal DNA (rDNA) locus; this sequence (length approximately 810 nucleotides) is often used as a "barcode" for Phytophthora spp. ITS
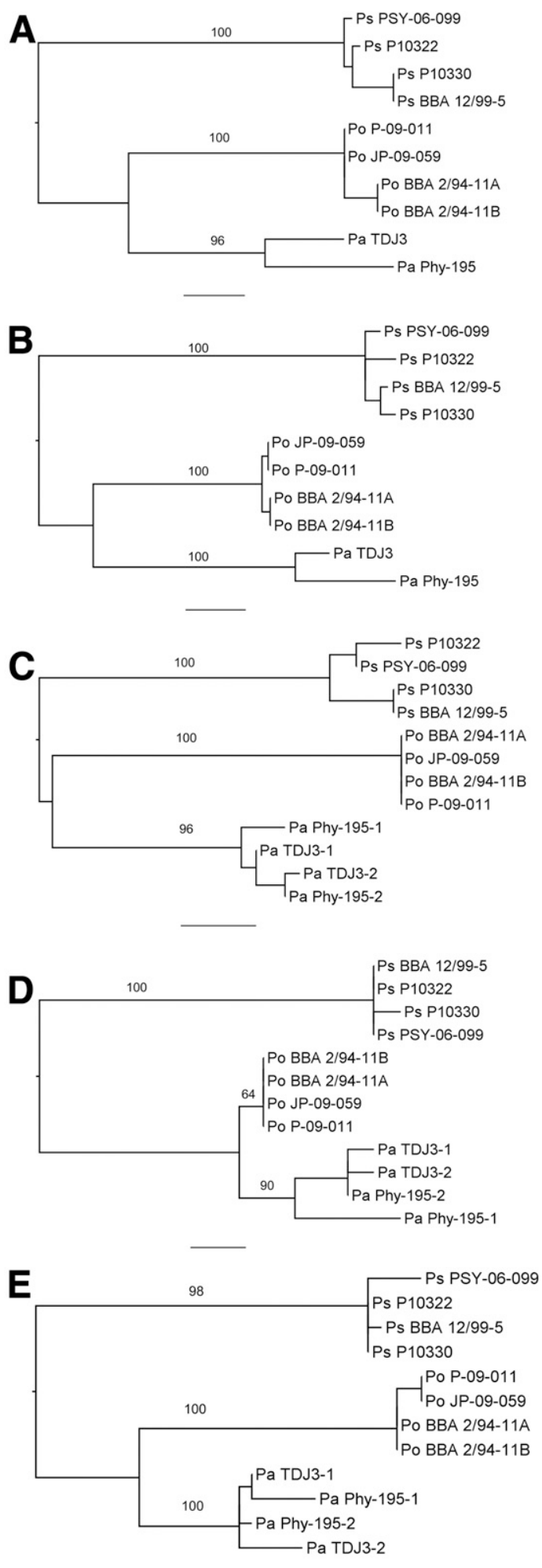

Fig. 7. Maximum-likelihood phylogenetic trees for the concatenated cox loci and four individual nuclear loci. Percent bootstrap values are shown for the interspecific branches. Species names are abbreviated: $\mathrm{Pa}=$ Phytophthora austrocedri, $\mathrm{Po}=P$. obscura, and $\mathrm{Ps}=P$. syringae. Scale bar $=0.05$. A, Partial $\operatorname{cox} 2$ and $\operatorname{cox} 1 ; \mathbf{B}$, heat shock protein $90 ; \mathbf{C}, \beta$-tubulin; D, 60S ribosomal protein; and $\mathbf{E}$, elongation factor $1 \alpha$. 
sequences from the two $P$. austrocedri lineages shared numerous differences from P. obscura (20 nucleotides; $2.5 \%$ ) and P. syringae (32 or 33 nucleotides; $4 \%$ ). There were three heterozygous sites within the P. austrocedri isolates. However, we were unable to assess the frequencies of the polymorphic alternatives among the multiple copies of the rDNA.

\section{DISCUSSION}

P. austrocedri is an emerging pathogen of A. chilensis in Argentina and of J. communis in Britain. From amplified fragment length polymorphism analyses, it was found that the ARG isolates exhibit very little genetic variation (Vélez et al. 2014). Our study has demonstrated that, across a number of nuclear and mitochondrial DNA genes, multiple ARG isolates are identical, as are multiple UK isolates, but that isolates from the two locations have distinct sequences. Thus, both outbreaks appear to be due to the spread of clonal lineages. Shared heterozygous positions in their $\beta$-tubulin, $R P L 10$, and $E F-1 \alpha$ genes suggest that both lineages originated from the same recombining ancestral population. One isolate from $J$. horizontalis in Germany appears to be identical to the ARG lineage.

This scenario described for $P$. austrocedri is not unusual for Phytophthora spp., whose invasive clones have caused widespread damage to herbaceous and woody plants globally, perhaps the most famous examples being the potato late-blight pathogen $P$. infestans (Goss et al. 2014) and the forest pathogens P. cinnamomi (Dobrowolski et al. 2003) and $P$. ramorum (Goss et al. 2009). Populations of heterothallic Phytophthora spp. such as P. infestans, P. cinnamomi, and $P$. ramorum can even remain clonal in geographic areas of introduction where both mating types exist; in the case of $P$. ramorum, controlled crosses of the two mating types failed to produce viable oospores (Grünwald et al. 2009). It has been suggested that clonality may, indeed, be an advantage for plant pathogens introduced to a new environment in which hosts are highly susceptible and there is no fitness advantage in sexual reproduction (Dobrowolski et al. 2003). Questions abound, however, as to the size of source populations because the geographical origins of most invasive Phytophthora spp. either have not been discovered or have not been sufficiently sampled. In the case of $P$. ramorum, where the source population is unknown, Goss et al. (2009) found strong evidence for recombination among three lineages invasive in North America (NA1 and NA2) and Europe (EU1), such that the ancestors of each lineage probably arose from the same sexually reproducing population. We also found evidence for historical recombination between the two founders of the P. austrocedri epidemics in Britain and Argentina, showing that sexual reproduction occurred to an unknown extent in the ancestral population. Evidently, somewhere in the world, there exists a potentially large and genetically diverse source population of $P$. austrocedri that has spawned both of these epidemics, with associated ramifications for global forest biosecurity. Missions to investigate the center of origin of this and other Phytophthora spp. should be undertaken so that potentially highrisk pathways from source regions can be identified and efforts focused on preventing future interregional spread of these pathogens.

For taxonomic purposes, genetically distinct clonal Phytophthora populations tend to be designated as lineages within the species delineation. For example, there are now four known clonal lineages of $P$. ramorum invasive in North America and Europe (Van Poucke et al. 2012) and two clonal lineages of another forest pathogen, P. lateralis (Brasier et al. 2012), which is also invasive in North America and Europe. Isolates of $P$. lateralis from Taiwan, associated with native Chamaecyparis spp. but not causing notable disease, were found to be more genetically variable and assumed to lie within the geographical center of origin of the pathogen (Brasier et al. 2012). The UK and ARG/GER isolates of $P$. austrocedri clearly represent distinct, apparently clonal lineages. Across the mitochondrial DNA sequences surveyed, these two lineages are more divergent than the invasive lineages of $P$. ramorum or $P$. lateralis, and also show more divergence than has been found thus far within the other clade $8 \mathrm{~d}$ species, $P$. syringae and $P$. obscura
(Table 3). Nevertheless, heterozygous positions in the $\beta$-tubulin, $R P L 10$, and $E F-1 \alpha$ genes shared between the UK and ARG lineages of $P$. austrocedri suggest that they were derived from the same ancestral source. An ongoing genome-wide sequencing study of a range of $P$. austrocedri isolates from Britain and Argentina will help to clarify further the degree of genetic differentiation within and between lineages and the extent to which each lineage has been evolving within its area of introduction.

ARG isolates of $P$. austrocedri grew more uniformly on agar than UK isolates, which presented a variety of colony types, with isolate GK3 generally growing faster than other UK isolates. It is difficult to interpret the significance of different colony forms across cultures derived from a single hyphal fragment of the parent isolate and when isolates have been in laboratory storage for different periods and often subcultured many times. Nonetheless, colonies of ARG isolates could be visibly distinguished from those of UK isolates. In terms of the morphology of reproductive structures, the UK and ARG isolates are similar, with the morphological dimensions obtained in this study agreeing with the original description of ARG isolates by Greslebin et al. (2007). Isolates from both lineages are homothallic, with no clear differences in the dimensions of their reproductive structures. The main distinguishing morphological features between the two lineages are that ARG isolates failed to produce sporangia on solid media and had thin oospore walls and a very high rate of oogonia abortion. The high rate of oogonia abortion in ARG isolates, not mentioned by Greslebin et al. (2007), is intriguing and may suggest genetic instability, perhaps acquired through time in storage. Oogonia abortion in oomycetes has also been found to be influenced by sterols in the culture media (Elliott and Sansome 1977). If wild isolates of the ARG lineage also have such a high degree of self-sterility, this may help to explain the clonal spread of this lineage within Argentina.

Another notable feature distinguishing UK and ARG isolates was the significantly slower growth rate of UK isolates across a range of solid media and across different temperatures; whereas all $P$. austrocedri isolates failed to grow at 25 or $30^{\circ} \mathrm{C}$, only UK isolates failed to grow at $22.5^{\circ} \mathrm{C}$. Although other oospore-producing, cool-temperature Phytophthora spp. occur in regions with hot summers, such as the Mediterranean (Pérez-Sierra et al. 2013), it is nonetheless hypothesized that the founder population of $P$. austrocedri has evolved in a cool, wet region where hot summers are infrequent. In the pathogenicity assays, the ARG isolate caused significantly longer lesions on A. chilensis than on J. communis, and vice versa for the UK isolate. A greater number of UK and ARG isolates, as well as the GER isolate, would need to be tested before the lineages could truly be differentiated by pathogenicity. Notably, however, both isolates were able to cause disease on both hosts, with the known host range of $P$. austrocedri encompassing a number of genera within the family Cupressaceae.

The lack of genetic diversity found in UK isolates and their aggressiveness on a native host lends support to the hypothesis that $P$. austrocedri is a fairly recent introduction into Britain (Green et al. 2015). However, the pathways by which a single clone of the pathogen has spread to infect J. communis at a range of geographically separate sites in northern Britain remain unclear. Unlike the contiguous forests of Patagonia, in which A. chilensis is a key component, populations of $J$. communis in Britain tend to be small, fragmented, and geographically distant from each other. DNA of $P$. austrocedri has been detected in soil at infected J. communis sites in Britain (Elliot et al. 2015) and soil transfer may occur over longer distances through human activity and movement of livestock, wildlife, and, potentially, infested nursery stock used for restoration plantings. The pathogen is most likely to survive and be transmittable in soil as sexually produced oospores, although it is currently unknown whether oospores give rise to viable progeny; work is ongoing to assess this. Given the clonal nature of the isolates collected to date, we suggest that the method of dispersal of $P$. austrocedri in Britain has been purely asexual. Low-level ( $<1.5 \mathrm{~m}$ in height) aerial infections have been found on J. communis in Britain (Green et al. 2015) but longer-distance aerial spread of $P$. austrocedri is deemed unlikely, even in a windy climate, 
because its sporangia are noncaducous and aerial infections have never been observed on A. chilensis in Argentina (A. Greslebin, Universidad Nacional de la Patagonia, personal communication; and M. L. Vélez, Centro de Investigación y Extensión Forestal Andino Patagónico, personal communication). Further research is needed to investigate the mechanisms of spread of $P$. austrocedri, including the relative roles of zoospores and oospores in initiating new infections.

Because the geographical origin and native hosts of $P$. austrocedri are currently unknown, it is hard to define appropriate biosecurity measures that could prevent further introductions from the source into new, potentially vulnerable ecosystems such as the Pacific Northwest of the United States, where the susceptible species $C$. lawsoniana and Calliptropsis nootkatensis occur naturally. The greatest known risk of inadvertent spread of $P$. austrocedri internationally is via the plant trade, because DNA of the pathogen has been found in diseased tissues of young Juniperus spp., Chamaecyparis lawsoniana, and Cuppressocyparis leylandii imported into Britain from other European Union countries (J. Barbrook, Animal and Plant Health Agency, York, England, personal communication; and A. Schlenzig, Science and Advice for Scottish Agriculture, Edinburgh, Scotland, personal communication). Indeed, isolate BBA in this study that is of the ARG lineage was obtained from an import nursery in Germany 15 years ago and it could be assumed that both lineages are being circulated in traded plants. Currently, U.K. Plant Health records of $P$. austrocedri in trade are based on DNA detection methods that do not distinguish between the UK and ARG genotypes. Given the differences in phenotype identified in this study, we strongly recommend that the UK and ARG lineages of $P$. austrocedri should be recognized as separate risks and treated accordingly in international plant health legislation, with detection protocols that distinguish by lineage.

\section{ACKNOWLEDGMENTS}

We thank A. Greslebin (Universidad Nacional de la Patagonia, Esquel, Argentina) and L. Vélez (Centro de Investigacion y Extensión Forestal Andino Patagónico, Esquel, Argentina) for supplying Argentinian isolates, S. Werres (Julius Kühn-Institut, Braunschweig, Germany) for supplying isolate BBA, S. Seddaiu for collecting two of the British isolates used in this study, M. Elliot and M. Gonzilez Romero for laboratory assistance, J. Forster and A. Peace for statistical support, J. Risse and F. Turner (Edinburgh Genomics) for phasing of the haplotypes, A. Schlenzig and R. Campbell (Science and Advice for Scottish Agriculture) for providing and maintaining the quarantine greenhouse used for pathogenicity testing, and the Royal Horticultural Society for funding the molecular work. This work was funded by the Forestry Commission and performed under Scottish Government Plant Health Order 2005 License PH-232016.

\section{LITERATURE CITED}

Blair, J. E., Coffey, M. D., Park, S. Y., Geiser, D. M., and Kang, S. 2008. A multi-locus phylogeny for Phytophthora utilizing markers derived from complete genome sequences. Fungal Genet. Biol. 45:266-277.

Bonants, P., Hagenaar-de Weerdt, M., van Gent-Pelzer, M., Lacourt, I., Cooke, D., and Duncan, J. 1997. Detection and identification of Phytophthora fragariae Hickman by the polymerase chain reaction. Eur. J. Plant Pathol. 103:345-355.

Brasier, C. M., Beales, P. A., Kirk, S. A., Denman, S., and Rose, J. 2005. Phytophthora kernoviae sp. nov., an invasive pathogen causing bleeding stem lesions on forest trees and foliar necrosis of ornamentals in the UK. Mycol. Res. 109:853-859.

Brasier, C. M., Franceschini, S., Vettraino, A. M., Hansen, E. M., Green, S., Robin, C., Webber, J. F., and Vannini, A. 2012. Four phenotypically distinct lineages in Phytophthora lateralis. Fungal Biol. 116:1232-1249.

Cooke, D. E. L., Drenth, A., Duncan, J. M., Wagels, G., and Brasier, C. M. 2000. A molecular phylogeny of Phytophthora and related oomycetes. Fungal Genet. Biol. 30:17-32.

Dick, M. W. 1990. Keys to Pythium. University of Reading Press, Reading, United Kingdom.

Dobrowolski, M. P., Tommerup, I. C., Shearer, B. L., and O'Brien, P. A. 2003. Three clonal lineages of Phytophthora cinnamomi in Australia revealed by microsatellites. Phytopathology 93:695-704.

Elliot, M., Schlenzig, A., Harris, C., Meagher, T., and Green, S. 2015. An improved method for the qPCR detection of Phytophthora spp. in forest and woodland soils in northern Britain. For. Pathol. 45:537-539.
Elliott, C. G., Hendrie, M. R., and Knights, B. A. 1966. The sterol requirement of Phytophthora cactorum. J. Gen. Microbiol. 42:425-435.

Elliott, C. G., and Sansome, E. 1977. The influence of sterols on meiosis in Phytophthora cactorum. J. Gen. Microbiol. 98:141-145.

Erwin, D. C., and Ribeiro, O. K. 1996. Phytophthora Diseases Worldwide. American Phytopathological Society Press, St Paul, MN.

Goss, E. M., Carbone, I., and Grünwald, N. J. 2009. Ancient isolation and independent evolution of the three clonal lineages of the exotic sudden oak death pathogen Phytophthora ramorum. Mol. Ecol. 18:1161-1174.

Goss, E. M., Tabima, J. F., Cooke, D. E. L., Restrepo, S., Fry, W. E., Forbes, G. A., Fieland, V. J., Cardenas, M., and Grünwald, N. J. 2014. The Irish potato famine pathogen Phytophthora infestans originated in central Mexico rather than the Andes. Proc. Nat. Acad. Sci USA. 111:8791-8796.

Green, S., Elliot, M., Armstrong, A., and Hendry, S. J. 2015. Phytophthora austrocedrae emerges as a serious threat to juniper (Juniperus communis) in Britain. Plant Pathol. 64:456-466.

Green, S., Hendry, S. J., MacAskill, G. A., Laue, B. E., and Steele, H. 2012. Dieback and mortality of Juniperus communis in Britain associated with Phytophthora austrocedrae. New Dis. Rep. 26:2.

Green, S., MacAskill, G. A., Dun, H., Armstrong, A. C., and Henricot, B. 2016. First report of Phytophthora austrocedri infecting Nootka cypress in Britain. New Dis. Rep. 33:21.

Greslebin, A. G., and Hansen, E. M. 2010. Pathogenicity of Phytophthora austrocedrae on Austrocedrus chilensis and its relation with mal del ciprés in Patagonia. Plant Pathol. 59:604-612.

Greslebin, A. G., Hansen, E. M., and Sutton, W. 2007. Phytophthora austrocedrae sp. nov., a new species associated with Austrocedrus chilensis mortality in Patagonia (Argentina). Mycol. Res. 111:308-316.

Grünwald, N. J., Goss, E. M., Ivors, K., Garbelotto, M., Martin, F. N., Prospero, S., Hansen, E., Bonants, P. J. M., Hamelin, R. C., Chastagner, G., Werres, S., Rizzo, D. M., Abad, G., Beales, P., Bilodeau, G. J., Blomquist, C. L., Brasier, C., Brière, S. C., Chandelier, A., Davidson, J. M., Denman, S., Elliott, M., Frankel, S. J., Goheen, E. M., de Gruyter, H., Heungens, K., James, D., Kanaskie, A., McWilliams, M. G., Man in 't Veld, W., Moralejo, E., Osterbauer, N. K., Palm, M. E., Parke, J. L., Sierra, A. M. P., Shamoun, S. F., Shishkoff, N., Tooley, P. W., Vettraino, A. M., Webber, J., and Widner, T. L. 2009. Standardizing the nomenclature for clonal lineages of the sudden oak death pathogen, Phytophthora ramorum. Phytopathology 99:792-795.

Grünwald, N. J., Werres, S., Goss, E. M., Taylor, C. R., and Fieland, V. J. 2012. Phytophthora obscura sp. nov., a new species of the novel Phytophthora subclade 8d. Plant Pathol. 61:610-622.

Guindon, S., Dufayard, J. F., Lefort, V., Anisimova, M., Hordijk, W., and Gascuel, O. 2010. New algorithms and methods to estimate maximum-likelihood phylogenies: Assessing the performance of PhyML 3.0. Syst. Biol. 59:307-321.

Hall, T. A. 1999. BioEdit: A user-friendly biological sequence alignment editor and analysis program for Windows 95/98/NT. Nucleic Acids Symp. Ser. 41:95-98.

Hothorn, T., Bretz, F., and Westfall, P. 2008. Simultaneous inference in general parametric models. Biom. J. 50:346-363.

Kroon, L. P. N. M., Bakker, F. T., Mvan den Bosch, G. B., Bonants, P. J. M., and Flier, W. G. 2004. Phylogenetic analysis of Phytophthora species based on mitochondrial and nuclear DNA sequences. Fungal Genet. Biol 41:766-782.

Martin, F. N., Blair, J. E., and Coffey, M. D. 2014. A combined mitochondrial and nuclear multilocus phylogeny of the genus Phytophthora. Fungal Genet. Biol. 66:19-32.

Martin, F. N., and Tooley, P. W. 2003. Phylogenetic relationships among Phytophthora species inferred from sequence analysis of mitochondrially encoded cytochrome oxidase I and II genes. Mycologia 95:269-284.

Pérez-Sierra, A., López-García, C., León, M., García-Jiménez, J., Abad-Campos, P., and Jung, T. 2013. Previously unrecorded low temperature Phytophthora species associated with Quercus decline in a Mediterranean forest in eastern Spain. For. Pathol. 43:331-339.

Thompson, J. D., Higgins, D. G., and Gibson, T. J. 1994. CLUSTAL W: Improving the sensitivity of progressive multiple sequence alignment through sequence weighting, position-specific gap penalties and weight matrix choice. Nucleic Acids Res. 22:4673-4680.

Van Poucke, K., Franceschini, S., Webber, J. F., Vercauteren, A., Turner, J. A., McCracken, A., Heungens, K., and Brasier, C. M. 2012. Discovery of a fourth evolutionary lineage of Phytophthora ramorum: EU2. Fungal Biol. 116:1178-1191.

Vélez, M. L., Coetzee, M. P. A., Wingfield, M. J., Rajchenberg, M., and Greslebin, A. G. 2014. Evidence of low levels of genetic diversity for the Phytophthora austrocedrae population in Patagonia, Argentina. Plant Pathol. 63:212-220.

Werres, S., Elliot, M., and Greslebin, A. 2014. Phytophthora austrocedrae Gresl. \& E. M. Hansen. Online publication. JKI Datasheets Plant Diseases and Diagnosis, Julius Kühn-Institut. doi:10.5073/jkidspdd.2014.001

White, T. J., Bruns, T., Lee, S., and Taylor, J. W. 1990. Amplification and direct sequencing of fungal ribosomal RNA genes for phylogenetics. Pages 315-322 in: PCR Protocols-A Guide to Methods and Applications. M. Innis, D. H. Gelfand, J. J. Sninsky, and T. J. White, eds. Academic Press, San Diego, CA. 